\title{
What counts as a linguistic border, for whom, and with what implications? Exploring Occitan and Francoprovençal in Rhône-Alpes, France
}

\author{
Michel Bert (DDL, Université Lumière/Lyon2) \\ michel.bert@univ-lyon2.fr \\ James Costa (ICAR, Institut français de l'éducation/ENS de Lyon) \\ james.costa@ens-lyon.fr
}

\section{Introduction}

Debates on the limits of the numerous Romance varieties spoken in what was once the western part of the Roman Empire have been rife for over a century (e.g. Bergounioux, 1989), and generally arose in the context of heated discussions over the constitution and legitimation of Nation-states. More recently, the creation of new administrative regions within the context of the European Union has also sparked a lively debate on the names and limits of languages as those institutions seek to legitimise their existence drawing on historical and linguistic elements.

The current debates on limits between language varieties in what is essentially a continuum of related forms of speech are by no means new. The nature of those limits was especially important in the $19^{\text {th }}$ century as Nation States sought to found their existence on cultural and linguistic homogeneity. The linguistic bipartite division of France between French, the language of the north, and Occitan, spoken in the south was clearly problematic for philologists, especially in northern France, and politicians alike. This original bipartition was to be erased gradually, as Occitan relentlessly recedes as the language of everyday interactions in the south. The shameful existence of Occitan, and the ideological problems this generated for the construction of a homogeneous nation, later led the linguist Bernard Cerquiglini (2007) to call Occitan the Iron-mask.

Situated at a distance from the major centres of debate on French and Occitan, removed from the major debates that have taken place over regional languages in France since the 1960s (in the Basque Country, Brittany, Catalonia, Provence etc.), the Rhône-Alpes region is a recent administrative construct that was organised around Lyon, one of the major centres for the diffusion of French from the $17^{\text {th }}$ century onwards. It is nevertheless traversed by several linguistic limits, the main one being the border between Occitan and Francoprovençal.

While issues generated by questions of limits had so far remained within the relatively closed domain of linguistics, the emergence of an interest in language policy on the part of the regional government is currently modifying previous equilibriums. This recent intervention of a new social actor in language debates calls for a reassessment of the role of limits regionally. Indeed, linguistic limits often tend to be constructed as boundaries by the implementation of measures of language policy, with effects in terms of language education planning for instance.

In Rhône-Alpes, linguistic limits are now gaining importance because they are seen as one potential tool for the legitimation of the existence of the région. In fact, while the regional government is promoting both Occitan and Francoprovençal on an equal footing, it 
is concomitantly downplaying the importance of this internal boundary to promote a feeling of linguistic closeness that would help legitimise its own existence as a coherent cultural area.

In this particular context, the link between identity and language is naturally of a rather complex nature. Given the number of social actors involved, and the differences in conceptualising identity that this diversity entails, we have chosen to follow Avanza \& Laferté's (2005) sociological approach to identity and thus to break up this notion into three more specific categories. To them, identity is best approached in terms of identification, social image and belonging. Identification refers to the process through which individuals are ascribed to particular categories (for example ethnicity or religion) by legitimate institutions. Social image refers to the production of discourses, images and symbols designed to represent a particular group or territory. Again, social images can be produced by institutions, but also by various types of associations and groups (e.g. NGOs) as well as by travel guides. The issue at stake is the production of an authoritative representation of a social group or geographic area through discourse. This is typically an area where the production of what counts as accepted and shared reality is created, reproduced or contested. The final category, belonging, refers to what groups or individuals tend to affiliate with. Such groups can include ethnolinguistic groups when the categories are available, and belonging is constantly subject to reproduction, renegotiation or contestation, internally or externally.

Based on several years of ethnographic sociolinguistic and dialectological research in the Rhône-Alpes and Provence regions in south-eastern France (see for instance Bert, 2001; Costa, 2010), this chapter focuses on how social actors construct limits with language, and why. We are therefore asking the following questions: to whom are limits important? Who can turn limits into boundaries, that is, legitimised limits with concrete effects on groups and individuals in terms of the creation of social difference? How are those limits constructed in discourse and spatial representations? And, most importantly for social actors themselves, what does this entail in terms of identity for the different groups involved? The types of actors we focus upon in this chapter are linguists, speakers, language advocates and institutions (the State and the regional government - or Conseil Régional - based in the regional capital, Lyon).

This chapter first presents the Rhône-Alpes region as one where linguistic limits are particularly salient and meaningful for an array of different social actors. We then analyse how traditional social actors (linguists, speakers, language advocates) construct limits through language (or refrain from doing so), emphasising convergences and divergences between those limits. We finally explore the role of the regional government (as well as of the State) in naturalising or contesting limits, and in legitimising certain boundaries through language policy, at the expense of others.

\section{Language(s) in the Rhône-Alpes region.}

The current French administrative regions (there are twenty-two in 2012) were created, one could say invented, between 1942 and 1960. They were subsequently given more power by the central Government between 1972, when the regions were transformed from economic to administrative entities, and 1982, when the newly elected socialist Government passed a series of major decentralisation laws.

All republican governments in France have consistently striven not to revive the Provinces that composed the Kingdom of France until the Revolution at the end of the $18^{\text {th }}$ 
century. Thus two centuries later, the new régions are composed of several départements ${ }^{1}$ but they are purposely created so as not to replicate the borders of the former Provinces. The Rhône-Alpes region, for example, comprises parts of the former provinces of Lyonnais, Languedoc, Dauphiné, Burgundy, and Savoy (see map 1, below). It should be noted that Savoy is itself a recent addition to France; it was annexed in 1860 together with the County of Nice at the time when the Italian State was formed. During the process that saw the establishment of régions, even long-established entities such as Brittany were partly dismantled, and the Nantes region (the Loire-Atlantique département) was joined to four others to form the Pays de la Loire region. Conversely, Provence was incorporated in a wider region called Provence-Alpes-Côte d'Azur with the former County of Nice and parts of the Dauphiné (and, until 1970, with Corsica). Finally, regions such as the Région Centre or Rhône-Alpes are new names invented in the 1960s and based on geographic features. RhôneAlpes itself consists of eight départements (see below, map 2$)^{2}$, thus constituting a very large area (43,698 square kilometres).

\section{MAP OF PROVINCES / REGIONS}

Map 1: The Rhône-Alpes region in France, and the main provinces that existed in south-eastern France before the Revolution ${ }^{3}$.

In a context where any distinctive particularity can be seen as a potential threat to French unity, it comes as no surprise that no cultural or linguistic elements were taken into account when the regions were designed. All the current regions of France, with the possible exceptions of Corsica and Alsace, embrace very diverse cultural and linguistic areas around a regional capital. Former or traditional limits were broken down and torn apart in order to create new, apparently more rational entities that could not be seen as competing with the citizen's main locus of identification, that is, the French nation.

As a region constructed by administrators, Rhône-Alpes is particularly emblematic of those new administrative units that paid no heed to limits that were meaningful to the populations. It therefore encompasses a multitude of historical, cultural and linguistic limits that still bear some effects in the everyday lives of people. In terms of linguistic situation, two Romance languages are traditionally spoken within the regional territory: Francoprovençal and Occitan ${ }^{4}$. While the départements of Ain, Isère, Loire, Rhône, Savoie and Haute-Savoie are usually described as Francoprovençal-speaking areas, most of the Ardèche and Drôme are habitually depicted as Occitan-speaking (see map 2 below for the départements of Rhône-Alpes, and map 3, showing the limit generally accepted by linguists and dialectologists between Occitan and Francoprovençal).

The reality of both ensembles is however more complex, and several important dialectal limits run through the Rhône-Alpes region, especially throughout the Occitan domain (see below, 3.2). Also, one must carefully differentiate between both languages: with

${ }^{1}$ In the administrative division of France, the département is one of the three levels of government below the national level. Départements were created during the revolution to break down former provinces, and now constitute an elected intermediate administrative level between the Communes (towns) and the Régions.

${ }^{2}$ On the process of région and département naming, see Boyer \& Cardy (2011).

${ }^{3}$ All maps, except map 3, were designed for this chapter by Olivier Bodson, whom we wish to thank here.

${ }^{4}$ The number of speakers of either language is now very low, with less than $1 \%$ of the regional population speaking either Occitan or Francoprovençal. Locally however, for example in Ardèche, Ain or Savoy, percentages can be significantly higher, especially among the older population (Bert, Costa \& Martin, 2009). The issues at stake here are therefore mainly symbolic. 
regard to Francoprovençal linguists tend to consider that there are no marked dialectal areas (Martin, 1990). Occitan in Rhône-Alpes, on the other hand, is usually divided between Provençal, in the south of Drôme and parts of southern Ardèche, Languedocien in southwestern Ardèche, and Vivaro-Alpin in the remaining parts of Drôme and Ardèche (see Sumien, 2009 for a summary of the classification of Occitan dialects).

\section{MAP OF DEPARTEMENTS}

\section{Map 2: Départments of Rhône-Alpes}

Francoprovençal and Occitan are both Romance languages that arose from the evolution of the Latin brought by Roman colonisers during the conquest of Gaul two thousand years ago. This particular brand of Latin evolved from a mostly Celtic (Gaulish) substratum, and was subsequently modified by the Germanic invasions that took place at the end of the Roman period and at the beginning of the Middle Ages. The relative importance of the Germanic superstratum is still a matter for debate, but most linguists consider that Francoprovençal was less affected by this latter influence than the Langue d'Oill domain, and Occitan even less so. Overall however, both languages are part of the same Romance continuum, and in our own experience are largely mutually comprehensible by competent speakers.

\section{LANGUAGES OF RHONE ALPES}

\section{Map 3: Francoprovençal and Occitan in Rhône-Alpes ${ }^{5}$}

Rhône-Alpes thus comprises a bundle of social, historical, cultural and linguistic limits. Conversely, some cultural limits are indexed through discourses on language. And the same limits are not meaningful in the same way to all social actors. The first social actors we review are linguists, whose historical role has consisted in the delimitation and naming of 'languages' in the modern sense of the term, as discrete and bounded entities, out of the Romance linguistics continuum.

\section{The languages of linguists: Occitan and Francoprovençal}

Linguists are central actors in the narrative we wish to recount here, in particular in the case of Francoprovençal. They are especially influential when it comes to processes of identification, as their work defines what limits are acceptable to delineate a language. This latter process in turn has consequences on how people appropriate, or reject, the language that linguists ascribe to them.

This section examines what limits are relevant to this category, and how linguists effectively generated borders that established Francoprovençal and Occitan as languages in

${ }^{5}$ Map courtesy of the Rhône-Alpes region. This map is used by the regional Government when promoting the language, and shows the limits between both languages as generally represented in traditional dialectology. 
their own right, in the modernist sense of the term - that is, as discrete and bounded entities connected to a well-identified territory.

\subsection{Occitan doubts and certainties}

The story of Occitan in its current form is now ancient and evolved mostly outwith the boundaries of what is now Rhône-Alpes. The administrative language of several areas in the Middle Ages, Occitan underwent a revival of interest from as early as the beginning of the $19^{\text {th }}$ century (see Martel, 2010a). What counted as Occitan was defined in the mid-nineteenth century by dialectologists (Merle, 2010), amateur philologists such as Simon Honnorat (Martel, 2010b; Merle, 1986) or Frédéric Mistral (Mistral, 1979 [1878]), the renowned Provençal writer and lexicologist ${ }^{6}$. The northernmost boundaries of Occitan were thus established long ago (and refined more recently - see Bert, 2001; Bouvier, 2003; Martin, 1979; Tuaillon, 1964), and run through the northern parts of the Ardèche and the Drôme départements (see map 4, below).

\section{MAP OF OCCITAN DIALECTS}

Map 4: Occitan dialects in France, Italy (eleven valleys in Piedmont) and Spain (the Val d'Aran in Catalonia)

Yet internal dialectal boundaries within Occitan are more problematic. The main limit for linguists is the ca/cha isogloss, which runs through the whole Occitan domain (and indeed throughout the whole Western Romania) from Italy to the Atlantic Ocean. South of that line one encounters such forms as cantar (to sing), vaca (cow) which are realised as chantar, vacha north of that limit. This particular limit serves to mark the distinction between northern Occitan dialects (Auvergnat, Limousin and Vivaro-alpin) and southern ones (Gascon, Languedocian and Provençal) ${ }^{7}$. As far as Rhône-Alpes is concerned, linguists do not recognise any east/west divide as particularly relevant to linguistics, and attribute no specific role to the Rhône in separating specific dialectal groupings.

\section{MAP OF THE CA/CHA LIMIT}

\section{Map 5: The ca/cha limit separating northern and southern Occitan dialects}

The work of linguists, while originally not meant for that particular purpose, in effect provides elements for different groups to identify with - hence the struggle that accompanied the establishment of Occitan as a distinct language. The existence of a sharp limit between a single Occitan language in the south of France, called langue d'oc throughout the $19^{\text {th }}$ century, and French in the north, is now a central one in French dialectology but its existence was the object of fierce philological disputes at the end of the $19^{\text {th }}$ century (Bergounioux, 1989). It could indeed be understood as questioning the unity of France and of the French people as one. Philologists such as Paul Meyer and Gaston Paris thus strove to prove that

\footnotetext{
${ }^{6}$ Mistral, who was the instigator of the Occitan language movement as we know it today and an inspiration for many revivalists, was awarded the Nobel Prize for his literary achievements in 1904.

${ }^{7}$ See also below, 4.2.2.
} 
there was indeed no real linguistic boundary, and that all the dialects of France formed a linguistic tapestry, gradually merging into one another to form a linguistic reality organised around Francien, in their view the former dialect of the Paris area.

It should also be noted that nowadays a few sociolinguists consider that Occitan is a recent invention, and that what actually exists is a mosaic of several 'Oc' languages (langueS d'Oc) (Lafitte \& Pépin, 2009). In effect, this would create boundaries within the Occitan domain of Rhône-Alpes, but it does not question the limit between Occitan and other languages north of the domain.

\subsection{Francoprovençal, an elusive linguistic reality}

What lies beyond Occitan, further north, is however less clear. Some speakers of what is now considered as Francoprovençal did become members of the Felibrige, the literary association established in 1854 in Provence by Frédéric Mistral to promote Occitan ${ }^{8}$. Yet, those authors from the Francoprovençal domain never sought to promote their own local varieties in their writings, and instead wrote in the standard Provençal that Mistral had codified. Those writers had no feeling of belonging to a common entity, and never referred to the dialects of their own areas as one language with its own particular name.

Nowadays however, linguists consider that present-day Romance-speaking France can be divided into three traditional linguistic domains: Langue d'oil in the North, Langue d'oc in the south and Francoprovençal. This latter domain was identified as a coherent linguistic area only in 1873 by the Italian dialectologist Graziadio Ascoli (1878 [1873]) within the context of the debate outlined above between Northern and Southern dialectologists regarding the existence of dialects in France.

Originally, Francoprovençal was defined not only because it displayed some unique and distinctive features, but also because it shared other features with either Occitan or Oïl varieties - hence its name, originally spelt as franco-provenzale. Other names have since been proposed by linguists to avoid confusion (Rhodanien, Moyen-rhodanien, Southeastern French, Burgondian - because of an alleged important Burgundian superstratum) but without ever being retained.

Yet, beyond the question of its name, the limits of Francoprovençal soon became an important issue, as their drawing encroached more or less upon other languages, Occitan in particular. Eventually, two sets of phonetic features were retained: linguists distinguished Francoprovençal from Occitan in relation to the particular treatment of Latin A (as in rosa, villa and so forth) when preceded by a palatal consonant, whereas the presence of words stressed on the penultimate syllable (paroxytons) was used to differentiate it from Oïl varieties in the north of the domain.

This linguistic domain was further legitimised by the broad conjunction of its shape and limits with that of the drawing of Roman roads leading from Lyon to Aoste in present-day Italy and Geneva in present-day Switzerland, as can be seen on Map 6 below. Within this particular framework, Lugdunum (Lyon), the religious capital of Gaul could then suitably be represented as a political centre that gave the necessary political impetus to the development of Francoprovençal as a discrete language.

\section{MAP OF ROMAN ROADS}

\footnotetext{
${ }^{8}$ For example, at the turn of the nineteenth and twentieth centuries, Paul Marietton in Lyon and the Abbé Cerlogne in the Val d'Aoste.
} 
Map 6: Roman roads from Lyon to Aoste and Geneva, and the Francoprovençal domain

It should be noted that, as far as linguists are concerned, there are no obvious internal dialectal boundaries in Francoprovençal, despite several attempts to establish some (Hasselrot, 1934; Martin, 1990). Thus, linguists do not construct internal limits as an issue, contrary to what takes place among activists (see below).

One may deem thoroughly arbitrary the operation that saw the birth of Francoprovençal as a language (see also Tuaillon, 1972); other choices may potentially have resulted in a different definition of that linguistic domain. Map 7 below shows the isoglosses that run from east to west through the Drôme département, some of which could indeed also have been chosen to draw a limit between both Occitan and Francoprovençal.

\section{MAP OF ISOGLOSSES DROME}

Map 7: Isoglosses running from east to west in the Drôme département (based on Bouvier, 1976)

The linguistic choices outlined above now have consequences on the lives of the people living in those areas that, at the end of the $19^{\text {th }}$ century, were largely unforeseen. In effect, Occitan has been taught in schools since 1951, yet Francoprovençal cannot be taught officially. The level of vitality and organisation of Occitan activism in Rhône-Alpes, due to the existence of strong activist networks in the Montpellier and Toulouse areas, is considerably higher than that of Francoprovençal.

At present however, there is a general consensus among linguists on both the existence of Francoprovençal as a language in its own right, and on the border between both languages in Rhône-Alpes. No obvious area of transition is ever retained on linguistic maps, and linguistic work carried out in the region is able to assign speech to either one or the other language. In doing so, linguists act as an organised body of scientists prescribing a particular type of identification with one language or another: a particular village or speaker is either connected to Occitan or to Francoprovençal.

It should finally be noted that one amateur linguist, Pierre Bonnaud, a former professor of geography at the Universite de Clermont-Ferrand in Auvergne, has argued in favour of the existence of one Medio-Romance language that would encompass what is currently known as Francoprovençal as well as the Occitan dialects of the Alps, Auvergne and Limousin. Such a proposal, had it been widely adopted, would have led to a considerably different linguistic panorama in Rhône-Alpes: Occitan would only be spoken in the far south, while most of the region would find itself almost homogeneously within the domain of 'Medioromance'?

\section{The voice of speakers and their perception of sociocultural limits}

This section will now turn to another sort of actors in the definition of linguistic limits. It present the various ways in which ordinary speakers of both Francoprovençal and Occitan conceptualise the limits of the local language they speak, and identify with such varieties to

\footnotetext{
${ }^{9}$ For a map of the 'Medioromance' area, see for example http://www.creuse.fr/IMG/pdf/16-Creusois23.pdf (accessed 20/07/2012).
} 
construct their identity as speakers of minorised regional languages. They are grouped together as there is no significant difference between the speakers of both languages as established by linguists.

\subsection{Language as a local reality}

To most ordinary speakers, i.e. speakers who do not consider themselves as language advocates or activists, the local language or patois as they still generally refer to it (Bert, Costa, \& Martin, 2009) is bounded either by their village, their travels or their social network. The names usually attributed to the patois, i.e. Patois of $X$, where $\mathrm{X}$ represents any given village, confirms this. The patois therefore fits a lived and close-by reality, and its boundaries fit those of personal experience. In terms of linguistic identity, individual belonging is therefore primarily connected with the village, possibly a grouping of a few villages, and, most importantly one speaker's limits may therefore not correspond to those of another speaker. Boundaries are thus traditionally not fixed, and can evolve according to interaction contexts, or to events such as the arrival of a newcomer.

For example, during the fieldwork we conducted in 2007-2008 for the Francoprovençal and Occitan in Rhône-Alpes (FORA) study (Bert et al., 2009), one woman in southern Drôme (aged 87) could therefore name the villages where, according to her, people spoke the same patois as she did - this included several towns and villages in the vicinity, but also the town of Montpellier several hundred kilometres south, where her son-in-law's father came from. Other nearby villages were however excluded from her list.

What is consistently confirmed however is a clear emphasis on the maximisation of difference with close-by localities (see also Dorian (1982) who comments on the obsession of speakers of endangered languages for variation), and a certain minimisation of foreignness with more distant locations. In other words, ordinary speakers identify linguistically with locality rather than with larger linguistic entities, which comes as no surprise. What is however more remarkable is the lack of correspondence between the limits drawn by linguists and those identified by speakers in their everyday discourse and practice, as will be shown in the next section.

\subsection{Divergence between linguists and ordinary speakers}

We have noted a definite lack of coincidence between the limits drawn by linguists and those meaningful to speakers. This is manifested both when speakers invoke limits that are irrelevant to linguists, but also through the fact that ordinary speakers usually thoroughly disregard the linguistic borders defined in linguistics.

\subsubsection{Alleged cultural limits expressed in linguistic terms}

To illustrate the first type of divergence, we take one particularly significant example in the Occitan domain, that of the Rhône. The Rhône is a major river that runs from north to south between Lyon and the Camargue area further south in Provence and flows into the Mediterranean. It marks the limit between the départements of Drôme and Ardèche in Rhône-Alpes, and further south between the Vaucluse in Provence and the Gard in Languedoc.

The Rhône corresponds to no particular isogloss, as indeed all major isoglosses run from east to west. The border between the Provençal and Languedocian dialects of Occitan lies further west on the Vidourle river. However, members of Occitan speech communities on both sides of the river consistently invoke the Rhône as a major linguistic border. People 
dwelling on the other side of the river are said to either speak very differently, even in a bizarre fashion, as in the case between areas in northern Drôme and Ardèche; or in some cases their speech remains unknown due to lack of contact.

Although the Rhône corresponds to no particular isogloss (see map 7, above), it has nevertheless been a political boundary since the early Middle Ages, if not before. It marked the border between the Kingdom of France and the Holy Roman Empire, between Provence and Languedoc. It now signals the difference between the Provence-Alpes-Côte d'Azur and Languedoc-Roussillon regions. In this particular case, it is therefore a stronger, sociohistorical, sense of belonging that generates a border that is subsequently connected with linguistic issues. In this case, linguistic limits are constructed on the basis of former political boundaries, whereas in historical modernity, linguistic limits are often naturalised into ideal, ethnic boundaries and subsequently used to delineate political entities.

\subsubsection{Limits established by linguists unnoticed in ordinary discourse and practice}

Conversely, ordinary speakers consider some essential limits established by linguists meaningless. We take three examples from different areas in Rhône-Alpes: 1. the northern border of Francoprovençal; 2. the border between Occitan and Francoprovençal; 3. an important dialectal border within Occitan, in the south of the region.

\section{a. The northern limit of Francoprovençal}

Our first example concerns the northern border of Francoprovençal. In the north west of the Francoprovençal domain, the accentuation on the penultimate syllable, the distinctive feature defining Francoprovençal in relation to Langue d'Oïl, has recently disappeared. As this is a recent evolution however, and as linguistic traces remain, linguists consider that what people speak in this area is still Francoprovençal.

However, in a local association of language enthusiasts where speakers from that area and from further south meet up on a regular basis, participants have consistently failed to notice the realisation of that particular accentuation, or lack thereof. In fact, when speakers resort to the written medium, some mark the unstressed final vowel and others do not. Yet this feature goes unnoticed in the ordinary speech of other fellow association members.

That is to say, that particular feature is not just unnoticed, it is not semiotised - it is not discursively constructed as a distinctive feature allowing the construction of difference between speakers.

\section{b. The Occitan / Francoprovençal border}

Our second example shows that such important linguistic limits as language borders can be meaningless to ordinary speakers. This example is drawn from fieldwork conducted by Michel Bert on the Occitan / Francoprovençal border (Bert, 2001), and more specifically in more than twenty villages at the limit between the north of Ardèche and the south-east of the Loire. As explained above, this limit is founded upon the difference of treatment of Latin A preceded by a palatal consonant. While it does not preclude mutual comprehension, this difference leads to important structural consequences on Francoprovençal, in particular in terms of verbal, nominal and adjectival morphology (such as different conjugational paradigms between verbs in $-a$ and verbs in $-i$ or $-\dot{e}$; feminine nouns and adjectives with final $-a$ or $-i$, vs. Occitan $-a$ ). 
Yet this feature went unnoticed by all speakers, except in one village (Tarantaise, where the speech is Occitan) where some had noticed that in Le Bessat (Francoprovençal), only a few kilometres away, some words ended in $-i$ instead of $-a$.

This shows last example is therefore particularly interesting, as it emphasise how different ideologies can lead to different constructions of speech as language, and how such differences we now deem essential can easily be dismissed within other ideological frameworks. Traditionally, speakers on both sides of what is now considered a linguistic border called their language patois, and difference was emphasised or downplayed for reasons of local politics rather than in relation with the establishment of wider entities we now call languages.

\section{c. The $c a / c h a$ limit within the Occitan domain}

Finally, we mentioned above (see map 5 above) the existence of an essential demarcation in Romance linguistics involving the evolution of Latin CA and GA. This line runs through the north of Italy and most of the Occitan domain, and allows to distinguish not only between northern and southern Occitan, but also between essential features of major European languages such as French, Spanish and Italian. Compare for instance French chanter, Francoprovençal, Rumantsch Grischun and Northern Occitan chantar vs. Southern Occitan, Catalan, Spanish cantar and Italian cantare. It is therefore of primary importance, and in some areas in Provence it permits the construction of northerners as Gavots, a mostly derogatory term.

However, essential as this border may be to linguists or speakers in other regions, speakers in the southern Drôme area who live on this very limit do not see it as it relevant, and in informal conversations seemed only to realise its existence when we happened to mention it. Even then, it was not seen as a relevant feature to create a difference between individuals and groups.

In the Suze-la-Rousse area in southern Drôme however, a much more important distinction consisted in the local, and often mentioned and laaghed about opposition between the pronunciation of the -ion/-ien suffix, for instance in the word informacion / informacien (information). This particular feature, more common in the Lower Provence area and relatively marginal in that area of northern Provence was constructed locally as a meaningful way to distinguish people.

Importantly, this emphasises the absence of predictability of what may or may not count as important linguistically in the construction of social difference. In terms of identity construction however, this means that identification (in this case by Academia) and folk feelings of belonging are potentially in conflict. As a consequence, 'speaking the same language' can indeed signify very different things to different people according to their ideological motivations.

\section{Language advocates: languages as bounded, discrete entities}

This section reviews the diverse positions adopted by language advocates or activists in Rhône-Alpes. Their position is a very complex one, as they must seek legitimacy from both science (mostly in order to gain access to symbolic and material resources allocated by the Institution) and the people (so as to be efficient in promoting the use of the language). In this respect, the histories of language advocacy diverge considerably on both sides of the Occitan/Francoprovençal border, mainly for reasons that originate outside Rhône-Alpes, in Provence and Languedoc. 
However diverse those movements may be, they are clearly part of a wider, panEuropean approach to language that tends to combine language, territory and identity in an essentialised fashion. Those social movements draw on linguistics to produce ideal linguistic territories with well-defined language boundaries.

\section{'Arpitan' \\ 5.1 Francoprovençal activism: from scattered local movements to the promotion of}

The existence of Francoprovençal activism is recent, little organised outside Savoy at least, and is less inclined to voice radical language policy claims than the Occitan movement. Francoprovençal was, until the 1960s, mostly the preserve of dialectologists. In the 1960s however, a brand of activism emerged in Savoy during the process that saw the establishment of the Rhône-Alpes region. Language was seen as a tool that supported the claim of Savoyard autonomists to demand the creation of a Savoy region within France (Bénédicte Pivot, 2012, personal communication).

It comes as no surprise that Savoyard language advocates were keen on promoting the existence of what they perceive and promote as a well-defined and well-delimited Savoyard dialect, although this corresponds to no particular linguistic evidence.

More recently, some younger Francoprovençal language advocates have sought to organise the movement around the concept of 'Arpitan', with some activists seeking to promote a common orthographic system and possibly a standard version of the language. The term Arpitan erases the potential idea that the language is a mixture of French and Provençal, and further naturalises it as a coherent, discrete and bounded domain with external boundaries. That is to say, Francoprovençal would no longer be the construction of a handful of linguists; it would be a language that was simply waiting to be discovered.

The aim of this latter movement is clearly part of a modernist project, and apparently seeks to fuse identification with belonging, and eventually with the production of social image through music, art and other cultural and political manifestations.

\subsection{The Occitan movement, 150 years later}

The Occitan movement is, on the other hand, far more ancient (in its modern form, it goes back to 1854), and far more complex (see for instance Abrate, 2001; Costa, 2010; Martel, 1987, 1989, 1997). The Occitan movement has since then been rife with ideological debates that served to express various statements of power. Debates on orthographic issues preceded and have accompanied the development of the Felibrige to the present day.

Other debates were to follow suit regarding the denomination of the language (langue d'oc or Occitan), and, more recently, there have been attempts to redefine the various dialects of Occitan as autonomous languages, thus turning internal dialectal boundaries into language boundaries. This means that according to what revival movement activists affiliate with, they do not construct linguistic borders, and accordingly their sense of belonging, in the same way. Consider the following two maps, which represent the meaningful borders according to whether one subscribes to an Occitanist view of the world (map 8), or to its Provençalist counterpart (map 9). The first point of view follows (and tends to reify) that of most linguists since the $19^{\text {th }}$ century, while the second adopts (and often essentialises) the point of view of some ordinary speakers from the Rhône area ${ }^{10}$.

\footnotetext{
${ }^{10}$ There is a general consensus in Romance linguistics to consider the Occitan domain as one single entity. Some sociolinguists, however, support the view that Provençal is a distinct language (e.g. Blanchet, 1992).
} 


\section{MAPS: OCCITANISTES / PROVENÇALISTES}

\author{
Map 8: The southern part of \\ Rhône-Alpes according \\ to the Occitan movement
}

\author{
Map 9: The same zone according to \\ promoters of Provençal as a distinct \\ language
}

In this case, language movements combine issues of identification and belonging, as such movements struggle to impose their own perception of regional linguistic identification. Each particular view in turn indexes different conceptions of culture and politics ${ }^{11}$ (Costa, 2011), and seeks to modify feelings of belonging of both a large number of language advocates and of ordinary speakers. A considerable target is also the institutional level, which is key to the legitimisation of identification processes, and to the production of social image aspect of identity. Ultimately however, what is at stake with the definition of limits as language boundaries is access to symbolic and material advantages, such as prestige and funding.

\section{Institutional voices: National and regional}

As stated in our introduction, what makes Rhône-Alpes particularly interesting and relevant to the study of language and borders is the recent emergence of a new, and inherently legitimate social actor in the process of language naming and delimiting, the regional Government. The regional government thus has the potential to generate social image, promote identification to its own vision of what it means to be rhonalpin, including linguistically, and to influence the sense of belonging of the inhabitants of the territory. In practice, it competes with an array of other types of actors, not least the state and the départements that compose the region.

The regional government has however adopted two main attitudes as far as regional linguistic boundaries are concerned: on the one hand, it has sought to legitimise and officialise the linguistic division of its territory externally, following the divisions identified (or chosen) by linguists, for example through its opposition to the national government in terms of language education planning. It has therefore advocated in favour of a wider national recognition for Francoprovençal in its current form. Simultaneously, it has attempted to partially erase that border internally, in order to justify the emergence of a Rhônalpine identity and to legitimise its existence as a recent administrative entity.

\subsection{Region and Nation}

The state is a particularly influential institution, as it controls the education system. As far as Occitan is concerned, the state has followed the boundaries established in the $19^{\text {th }}$ century, despite attempts by some Provençal language advocates to institute Provençal as a distinct entity.

It has been legal to teach some regional languages of France since 1951, but Francoprovençal is not part of them. Following language advocates' demands that the

\footnotetext{
${ }^{11}$ In particular, proponents of Provençal as a separate language tend to promote more keenly such cultural activities as the wearing of the Provençal costume, and to over-emphasise their ties with rural, workingclass Provence. On the other hand, they view the Occitan movement as middle-class led and oriented. No study has yet been conducted in terms of voting practices however.
} 
language be taught over the past twenty years, various government decisions have assigned Francoprovençal to either the Oïl domain (and therefore, as a dialect of French, it does not require particular teaching provisions), or as a dialect of Occitan, which can therefore be taught (see Grinevald \& Bert, forthcoming). The latter option is considered a nonsense by language advocates locally.

Legitimising the boundaries of Francoprovençal as established by linguists is therefore a strong requirement for the Rhône-Alpes regional Government in the establishment of a regional language policy that treats both regional languages on an equal footing. At an official level, only the borders defined by linguists carry enough weight to justify political action.

\subsection{Promoting a regional identity}

The interest of the regional government in the regional language spoken within the territory of the region began in 1007, when it commissioned a sociolinguistic survey on the use of Francoprovençal and Occitan (Bert, et al., 2009). Since then a number of measures of language policy were passed with respect to both languages.

Given the lack of either historical substance or cultural unity to justify and legitimise the existence of Rhône-Alpes, it is precisely this diversity that has come to characterise the region and the social image the local Government wished to promote in official discourse (see Costa \& Bert, 2011). Consider for example the following extract from the regional Government's website:

Rhône-Alpes tire son unité de ses mille et une facettes géographiques et climatiques. Mais ce sont avant tout ses habitants qui font chaque jour de Rhône-Alpes une région dynamique, attractive où il fait bon vivre. [...] La région Rhône-Alpes est placée au carrefour naturel de grands axes de communication nationaux et européens. Cette situation en fait une Région ou la diversité est le maître mot. Ce puzzle à la fois géographique, climatique, sociologique et culturel pourrait être un handicap. RhôneAlpes en a fait sa force ${ }^{12}$.

Rhône-Alpes draws its unity from its multifaceted geographic and climatic character. But above all, it is its inhabitants that relentlessly make Rhône-Alpes a dynamic, attractive region where life is agreeable. [...] The Rhone-Alpes region lies at a natural crossroads between major national and European roads. This situation makes the Region one where diversity is a central keyword. This geographic, climatic, sociological and cultural mosaic could be a handicap. Rhône-Alpes has made it its strength.

Of central importance is precisely the necessity to naturalise the existence of RhôneAlpes despite its recent creation, and to create a charter myth that ensures that the entity is legitimate as an administrative entity. In this respect, language proves to be a useful tool for the regional Government, which can focus both on linguistic diversity as part of its constitutive diversity, and on the closeness of both languages to assert the coherence of the region as more than an administrative construct.

Indeed, in its public documentation regarding the language as well as in the text that was provided to members of the regional assembly when the principle of a linguistic policy was first adopted, the language border tends to be erased (Costa \& Bert, 2011), in particular

\footnotetext{
${ }^{12}$ Rhône-Alpes Regional Council website, http://www.rhonealpes.fr/23-dynamisme-en-rhone-alpes.htm. Accessed 20 July 2012.
} 
through the use of the expression 'vernacular languages', that allows no language name to be given $^{13}$. Conversely the similarities between speech on both sides of the limit are emphasised, in order to contribute to legitimise the idea of Rhône-Alpes as a coherent ensemble. Thus, despite an official discourse on diversity, unity is still sought through the existence of common features such as language, in a movement that reproduces, in a much lighter version, the construction of France as 'one and indivisible' in the $19^{\text {th }}$ century.

Issues of limits and boundaries are, as we can see from this example, clearly connected to issues of social image production, and can be used to emphasise or neutralise tensions that can arise from the presence of diversity within a given territory. That is to say, limits can be transformed though discourse into difference or sameness, depending on what political agenda is at stake at the time when discourses are produced.

In our particular case, the limits of speakers are ignored by regional politics, because they emphasise the ultra-local. The limits of Savoyard as put forward by activists have also been erased for political reasons, in order to obliterate a potential conflict with the Savoyard autonomist movement, especially at a time when the region was also celebrating the $150^{\text {th }}$ anniversary of the union or annexation, depending on social actor's point of view, of Savoy to / by France. Finally, the region acknowledges and legitimised the Occitan vision of the south of the regional domain. This allows avoiding the creation of a new internal linguistic division, and aligns regional choices with those of other Occitan regions.

\section{Conclusion: Performing diverse and potentially conflicting aspects of identity}

That linguistic limits are social constructs is, of course, by no means a new element in the sociolinguistics of language borders. What makes this particular case interesting is both the lack of coincidence between the limits constructed by linguists and those meaningful to ordinary speakers. Language advocates and institutional actors are subsequently compelled to take position with respect to those diverging point of view. Significantly, the limits of speakers are usually disregarded. The meanings those limits convey wane with the gradual passing of traditional speakers. The ideologies that led to those limits are also disappearing, and new ideologies, based on the mutually legitimising alliance of linguistics and institutions, are gradually imposing a new type of discourse on the minority languages spoken in RhôneAlpes.

Linguists, speakers and activists therefore perform various, conflicting, aspects of identity though the semiotisation of linguistic features. In short, they carry out a type of struggle over classifications that index values and ideas that are far removed from linguistic concerns.

A first conclusion to this chapter could be that in Rhône-Alpes linguistic limits are important to every type of social actor involved with regional languages at different levels. Limits can subsequently be turned into boundaries for population management purposes, they can be used to generate or legitimise difference and identity.

A second conclusion, one with more long-term implications, would be that much more research is needed as to the type of social meaning that is invested by social actors in various interactional situations. This article only paints a very broad picture of a reality that remains much more complex. The type of linguistic policy that the Rhône-Alpes regional government wishes to implement is of course (for now) fairly inconsequential for most of the population

\footnotetext{
${ }^{13}$ Also, note that in French, the plural is not heard when the expression is used orally.
} 
of the region, given the small numbers of people involved. Yet it may trigger new dynamics, and generate new types of behaviour in link with the linguistic borders language policy inevitably creates or naturalises.

\section{References}

Abrate, L. (2001), Occitanie 1900-1968: des idées et des hommes, Puylaurens: Institut d'Etudes Occitanes.

Ascoli, G. I. [1873] (1878), 'Schizzi franco-provenzali', Archivio Glottologico Italiano, 3, 61-120.

Avanza, M., \& G. Laferté (2005), 'Dépasser la «construction des identités » ? Identification, image sociale, appartenance', Genèses, 61: 4, 134-152.

Bergounioux, G. (1989), 'Le francien (1815-1914) : la linguistique au service de la patrie', Mots. Les langages du politique, 19, 23-40.

Bert, M. (2001), Rencontre de langues et francisation : L'exemple du Pilat, $\mathrm{PhD}$ dissertation, Lyon: Université Lumière Lyon 2.

Bert, M., J. Costa \& J.-B. Martin (2009), Etude FORA: francoprovençal et occitan en RhôneAlpes, Lyon: Institut Pierre Gardette, INRP, ICAR, DDL.

Blanchet, P. (1992), Le provençal: Essai de description sociolinguistique et différentielle, Louvain-la-Neuve: Peeters.

Bouvier, J.-C. (1976), Les parlers provençaux de la Drôme. Etude de géographie phonétique, Paris: Klincksieck.

Bouvier, J.-C. (2003), 'L'occitan en Provence: le dialecte provençal, ses limites et ses variétés', in J.-C. Bouvier, Espaces du langage : géolinguistique, toponymie, culture de l'oral et de l'écrit, ed. C. Mauron \& J.-N. Pelen, Aix en Provence: Université de Provence, pp.11-25.

Boyer, H., \& H. Cardy (2011), 'Localiser, identifier, valoriser', Mots. Les langages du politique, 97: 3/2011, 5-13.

Cerquiglini, B. (2007), Une langue orpheline, Paris: Editions de Minuit.

Costa, J. (2010), Revitalisation linguistique: Discours, mythes et idéologies. Approche critique de mouvements de revitalisation en Provence et en Écosse, Ph.D. dissertation, Grenoble: Université de Grenoble.

Costa, J. (2011), 'Du local au global : essai de clarification idéologique préalable. Discours concurrents et revitalisation linguistique en Provence', in F. Manzano (ed.), Unité et diversité de la linguistique, Lyon: Publications du Centre d'Etudes Linguistiques / Editions de l'université Jean Moulin, Lyon 3, pp.233-255.

Costa, J., \& M. Bert (2011), 'De l'un et du divers. La région Rhône-Alpes et la mise en récit de ses langues', Mots. Les langages du politique, 97, 45-57.

Dorian, N. C. (1982), 'Defining the Speech Community to Include its Working Margins', in S. Romaine (ed.), Sociolinguistic Variation in Speech Communities, London: Edward Arnold, pp.25-33.

Grinevald, C. \& M. Bert (forthcoming), 'Whose ideology, where and when? Rama (Nicaragua) and Francoprovençal (France) experiences', in P. K. Austin \& J. Sallabank (eds.), Endangered Languages: Ideologies and Beliefs, Oxford: Oxford University Press.

Hasselrot, B. (1934), 'Le francoprovençal se compose-t-il de deux groupes principaux, un septentrional et un méridional ?', Studia Neophilologica, 7, 1-17. 
Lafitte, J., \& Pépin, G. (2009), La “Langue d'Oc” ou leS langueS d'oc?, Monein: Pyremonde / Princi Negue.

Martel, P. (1987), 'Vingt-cinq ans de luttes identitaires', in G. Vermes \& J. Boutet (eds.), France, pays multilingue. Les langues de France, un enjeu historique et social, Paris: L'Harmattan, vol. 1, pp.125-142.

Martel, P. (1989), 'Un peu d'histoire : bref historique de la revendication occitane, 19781988, Amiras / Repères occitans, 20, 11-23.

Martel, P. (1997), 'Le Félibrige', in P. Nora (ed.), Les Lieux de mémoire, Paris: Quarto Gallimard, vol. 3, pp.3515-3553.

Martel, P. (2010a), Les Félibres et leur temps : Renaissance d'oc et opinion (1850-1914), Bordeaux: Presses universitaires de Bordeaux.

Martel, P. (2010b), 'Du parler local à la langue : le docteur Honnorat à la découverte de l'unité de la langue d'oc', Chroniques de Haute Provence, 365, 35-66.

Martin, J.-B. (1979), 'La limite entre l'occitan et le francoprovençal dans le Pilat', Etudes foréziennes, $10,75-88$.

Martin, J.-B. (1990), 'Le francoprovençal', in H. Metzeltin \& C. Schmitt (eds.), Lexikon der Romanistischen Linguistik, Tübingen: Max Niemeyer, pp. 671-685.

Merle, R. (1986), 'Le chemin d'Honnorat: Histoire d'A, ou la langue telle qu'elle doit être', Amiras / Repères occitans, 13, 85-98.

Merle, R. (2010), Visions de "l'idiome natal" à travers l'enquête Impériale sur les patois (1807-1812) : langue d'oc, catalan, francoprovençal - France, Italie, Suisse, Perpinyà: E1 Trabucaïre.

Mistral, F. [1878] (1979), Lou tresor dóu Felibrige, Raphèle-les-Arles: Culture Provençale et Méridionale.

Sumien, D. (2009), 'Classificacion dei dialèctes occitans', Linguistica Occitana, 7, 1-56, available online: http://www.revistadoc.org/file/Lingistica-occitana-7-Sumien, accessed 20 July 2012.

Tuaillon, G. (1964), 'Limite nord du provençal à l'est du Rhône', Revue de Linguistique Romane, XXVIII, 127-142.

Tuaillon, G. (1972), 'Le franco-provençal: progrès d'une définition', Travaux de linguistique et de littérature, 10: 1, 293-339. 